Relations industrielles

Industrial Relations

\title{
Proposed Solutions
}

\section{Marcel Clément}

Volume 3, numéro 10, juin 1948

URI : https://id.erudit.org/iderudit/1023642ar

DOI : https://doi.org/10.7202/1023642ar

Aller au sommaire du numéro

Éditeur(s)

Département des relations industrielles de l'Université Laval

ISSN

0034-379X (imprimé)

1703-8138 (numérique)

Découvrir la revue

Citer cet article

Clément, M. (1948). Proposed Solutions. Relations industrielles / Industrial

Relations, 3(10), 157-160. https://doi.org/10.7202/1023642ar

Tous droits réservés (C Département des relations industrielles de l’Université Laval, 1948
Ce document est protégé par la loi sur le droit d'auteur. L'utilisation des services d'Érudit (y compris la reproduction) est assujettie à sa politique d'utilisation que vous pouvez consulter en ligne.

https://apropos.erudit.org/fr/usagers/politique-dutilisation/ 


\section{PROPOSED SOLUTIONS}

(from page 160)

pear. The autonomy of the group thus brought out is characterized by the fact that the parent enterprise will have no further relations with individual members of the group. The delegate, or head of the group, receives from the enterprise, represented by its ordinary technical staff, a certain price of work to accomplish for an agreed inclusive price. The general organization is in no way modified. Simply, it gets rid of the details of the particular job by placing at the disposal of the group the necessary buildings, equipment and raw material ».

From an inquiry conducted by the "Worker's Centre of Studies and Information», it is evident, however, that the workmen clearly see certain disadvantages of which they have already had experience. There is, above all, the fear that the delegated leader would obtain too much power. However, the proponents of the system affirm that these deviations can be easily rectified or even forestalled. The group is the Labour unit where the educating influence of responsibility and of team-work is exercised on the workman with the greatest intensity and under the most favorable conditions. To play this role, Monsieur Dubreuil estimates that four rules should be satisfied :

- Free recruiting of workers by their group constituted as a labour co-operative.

- Collective undertaking of a specific « job» for a price agreed upon between the employer and the representative of the group.

- Unrestricted choice of the leader of the group and untrammelled organizing for the production confided to the labour co-operative.

- Division of the total price of the « job » in wages among the workmen according to the method of allotment they themselves judge the best.

It is advisable nevertheless, to make two important observations :

1.- As regards the price arrangement, the representative of the self-governing team and the employer are not on an equal footing economically as they are (theoretically, at least) in the Workers' «Commandite ». There is no market within the enterprise; the workers' team remains a team of wage-earners of the entreprise; in case of a classing of interest the workers have at their disdisposal only the usual weapon of an appeal to the union and eventually, the strike. This discussion on price has only the appearance of an economic discussion. Its real scope is of a psychological kind in arousing the attention of the wage-earner to the concrete demands on the cost price and in arousing the attention of the entrepreneur to the concrete demands of the wage-earner's needs (physical, psychical, family and social) and to their real possibilities (physical, psychical and technical).

2.- The organizing of work in a self-governing team can never be entirely free as the group works with equipment furnished by the entrepreneur. Besides, the work of each team is inserted in the whole. Finally, the organizing of the work as such is only partially in the hands of the team which remains dependent, in different degrees, on the preparatory services of the establisment. So that the self-governing team, in the perspective of Labour organization appears to certain people as the last cry in the evolution of this organization, since it takes account of the human relations within the enterprise and of the need of initiative felt by the worker.

The Dubreuil-Remailho system has been applied with variations in many different enterprises. In the Ruinet factory at Dijon six sections or divisions were definedfi each directed by an employers' representative named by the management and a worker's representative named by his comrades. The employers' representative together with the workers' representative freely chose their fellowworkers subject only to veto by management. In each division a price was allocated for a definite piece of work. Production was calculated each day and the amount gained was divided according to a scale which took account of professional capacity, individual value, seniority and family responsibilities. Results were immediately apparent. The workers applied themselves to finding the best methods of working and of avoiding waste. Production was increased and team spirit replaced egoism. Other test have been made with comparable success in a shoe factory at Romans (Drome), in a bed factory at Saint Dié and in a manufacture of knitted goods etc . . .

In certain other enterprises an attempt was made to combine the division into self-governing teams with profit-sharing or the proportional wage. The idea being to associate by this second means, the worker with the profits and at the same time render the association, thanks to the system of division in to groups, freer and more personal in its action.

\section{V-The Boimondeau Community (Barbu System)}

One experience of these last seven years at Valence, France, must be mentioned briefly before terminating this paper. It is without doubt a case which does not fall under Reform of Structure 
and therefore is somewhat outside our discussion. But let us point out that this factory of BOItiers de MONtre du DEAUphiné (whence the name of BOIMONDEAU) is owned in common by a hundred workmen who live in a hard-working family community. These are then a hundred families who, after deductions of savings for investment, requirements of the treasury and coverage for risks, divide among themselves the funds remaining - actually the principle of the co-operative of production - but according to the «human values" professional, moral intellectual, physical, cultural and those of comradeship. It is most often the person concerned who rates himself, subject to questioning by any of the others. The work of the woman in the home, of the child at school also enters into the picture. Thus, the Community at Moimondeau is without doubt the most complete experiment ever attempted in the building of an economy for man rather than in the enslaving of man to economy. There is yet to be ascertained the role played by Monsieur Barbu who has known how to enthuse his companions and has made a success of a difficult experience partly because he was able to create the proper « climate ». Other communities are in process of formation. The future will tell whether under the empetus of other men these audacious experiments will meet with a success as real.

\section{Conclusion}

This rapid survey has no other purpose than to make employers and labour alike reflect on the sense and the reach of the evolution in which we are taking part. It is not to be denied that « liberalism 》 had treated labour as a commodity and man as a machine. Socialism arose in reaction but has produced nothing but the stifling effect of State Control. We must escape from the vicious circle. The boldest must know how to conceive of a New World essentially Christian in its spirit as in its institutions. Wise reform of structure, conceived of not augment profit but to permit the flowering of the personality of the worker, is the peaceful, legitimate and efficient means which offers itself now and to-day. God grant that such an evolution be brought to fulfilment by those very persons who, assuming the responsibilities of private enterprise are best placed to know that it is free enterprise which is at stake.

The hour is come to cease the quibbling which confuses the laissez-faire enterprise with free enterprise. Reforms in structure have no other end but to facilitate the passage from the one to the other.

\section{BIBLIOGRAPHIE}

\section{LA GAZETTE DU TRAVAIL}

Ce périodique mensuel du ministère fédéral du Travail entre dans sa quarante-huitième année. Le premier numéro qui comprend les mois de janvier et de février, nous est arrivé en fin de mars dans une toilette neuve et une présentation attrayante qui s'inspire du * Monthly Labor Review 》 des Etats-Unis. On a gardé les rubriques habituelles et groupé dans une partie spéciale toutes les statistiques du travail. Une abondance de graphiques et de sommaires au début de chaque partie permet aux lecteurs de saisir rapidement le contenu de chacun des numéros.

Jusqu'ici, cette revue a rendu des services inappréciables à tous ceux qui sont intéressés aux relations du travail. On y trouve une mine de renseignements et d'informations sur ces problèmes qui se présentent au Canada et dans les autres pays. Notre Gazette du Travail est avantageusement comparable aux publications officielles analogues. Nous nous permettons cependant de regretter que les statistiques ne soient pas aussi complètes qu'on le souhaiterait. Ainsi, il n'est fourni aucun chiffre sur la productivité, l'absentéisme, le roulement de la maind'oeuvre dans les industries. Cette lacune sera comblée quelque jour, nous l'espérons.

Depuis longtemps les lecteurs de langue française se plaignent à bon droit que la Gazette du. Travail ne leur parvienne que deux ou trois mois en retard. Nous espérions que les transformations récentes s'accompagneraient de la disparition de cette lacune qui fait perdre un certain intérêt à la revue et oblige ceux qui ont besoin d'une information, à s'abonner en même temps à l'édition anglaise et à l'édition française. Le tarif de l'abonnement, qui était autrefois de $\$ 0.20$ par année est majoré à $\$ 1.00$ pour le grand public et à $\$ 0.50$ comme prix spécial pour groupe afin de servir les besoins des syndicats, des étudiants, des entreprises, etc.

G.D.

\section{SECURITE SYNDICALE ET MORALE}

Le Département des relations industrielles de la Faculté des sciences sociales vient de faire éditer le magnifque travail que son secrétaire, M. l'abbé Gérard Dion, a présenté l'an dernier lors du deuxième congres des relations industrielles de Laval. Il s'agit d'une brochure intitulée: «Sécurité syndicale et morale \$."

A ceux qui ne sont pas engagés dans les relations du travail ou qui n'en suivent pas de près les développements, il convient de signaler l'importance et l'opportunité de cette étude.

Le style et le plan de cet ouvrage indiquent chez son auteur une pensée claire et ordonnée. Il a étudié un épineux problème dans toute son ampleur, en ne négligeant aucune objection et en ne s'épargnant aucune des difficultés que comportait le sujet.

Une brochure semblable mérite une large diffusion. Non seulement elle apporte aux principaux intéressés des précisions qui sont indispensables pour bien guider leur activité, mais encore elle fournit à ceux qui ne sont pas très initiés aux problèmes des relations du travail des apercus lumineux qui les font pénétrer au coeur de lun des problèmes les plus importants dans ce domaine.

(L'Action Catholique)

Gaston Choletre

(1) Brochure en vente à la Librairie de l'Action Catholique, Québec, et au Département des relations industrielles de Laval, 25 cents. 


\section{TABLE DE L'ANNÉE 1947-1948}

Accidents du travail, La compensation des - Frédéric $T$. Hecker, No 6, février, pp. 91-95.

Apprenticeship Commission in the building industry, An (A Realization) - J.L.E. Price, No. 10, June, pp. 153-155.

Association et corporation - No 3, novembre, pp. 44-46.

Bureau de placement, Un - Jean Gagné, No 3, novembre, pp. 43-44.

Cartels intersyndicaux, Unité syndicale et - Jean-Pierre Després, No 7, mars, pp. 106-108.

Cas pratique - Donat Quimper, No 2, octobre, p. 30.

Catholicisme social face aux grands courants contemporains - Lettre de Sa Sainteté Pie XII à M. Charles Flory, No 1, septembre, pp. 10-12.

Collective Labour Agreements, The Renewal Clause of Georges-Michel Giroux, No. 8, April, pp. 124-127.

Comité paritaire, Rôles respectifs du secrétaire et de l'inspecteur du - J.-Médard Ouellet, No 2, octobre, pp. 28-30.

Comités d'entreprises, Les - Raymond Gérin, No 8, avril, pp. 117-119.

Commission d'apprentissage des métiers du bâtiment, Une (Une réalisation) - J.L.E. Price, No 10, juin, pp. 151-153.

Communist Manifesto, The - Egbert Munzer, No. 7, March, pp. 103-106.

Congés annuels payés dans le Québec, Les - Charles Bélanger, No 10, juin, pp. 148-151.

Congrès, Notre troisième - La Direction, No 6, février, pp. 81, 95. Réflexions sur le troisième congrès La Direction, No 8, avril, p. 113. Echos du troisième congrès: Audace et franchise - Gaston Cholette, No 10, juin, p. 156. Building the Christian Social Order - Henry Sommerville, No. 10, June, p. 156.

Convention, Our third annual - The Editors, No. 6, February, p. 96. Some Reflexions on the Third Convention - The Editors, No. 8, April, p. 128.

Conventions collectives, Clause de renouvellement dans les - Georges-Michel Giroux, No 8, avril, pp. 119-122.

Coopération des patrons et des apprentis - J.L.E. Price, No 9, mai, pp. 137-139.

Co-operation in Apprenticeship Training, Labour management - J.L.E. Price, No. 9, May, pp. 139-141.

Corporation, Association et - No 3, novembre, pp. 44-46.

Décret, Rôles respectifs du secrétaire et de l'inspecteur du comité paritaire - J.-Médard Ouellet, No 2, octobre, pp. 28-30.

Démocratie ouvrière en oeuvre - Jean Gagné, No 2, octobre, pp. 22-26.

«Différend 》, Le sens des termes «salarié 》 et - MarieLouis Beaulieu, No 5, janvier, pp. 74-78.

Distributisme social et stabilité ouvrière - Gonzalve Poulin, o.f.m., No 1, septembre, pp. 8-10.

Editorial: Une troisième année - La Direction, No 1, septembre, p. 1. Rétrospective 1947 - La Direction, No 4, décembre, pp. 49-51.

Editorial: Our Third Year - The Editors, No. 1, September, p. 16. Retrospective 1947 - The Editors, No. 4, December, pp. 63-64.

Effectif syndical - No 3, novembre, pp. 46-47.

Enterprise, The Structure of - Marcel Clément, No. 6, February, pp. 87-91.

Enterprise, Property and - Paul-Emile Bolté, No. 3, November, pp. 40-41.

Entreprise, Propriété et - Paul-Emile Bolté, p.s.s., No 3, novembre, pp. 34-40.

Entreprise, La structure de l' - Marcel Clément, No 6, février, pp. 82-86.

Ethics in Labour Relations - Gaston Cholette, No. 2 , October, pp. 26-28.

Formation professionnelle, La - Gabriel Rousseau, No 8. avril, pp. 116-117.

Gazette du travail, La - G.D., No 10, juin, p. 158.

Grève politique ou grève économique - La Direction, No 2. octobre, p. 17.

Grèves, Réflexions sur les - Omer Genest, ptre, No 4, décembre, pp. 51-55.

Hygiène industrielle, Service d' - Gérard Dion, No 3, novembre, pp. 41-43.

Loi Taft-Hartley, La - Gérard Tremblay, No 1, septembre, pp. 2-5.
Manifeste communiste, Le - Egbert Munzer, No 7, mars, pp. 99-103.

Manuels techniques français - No 4, décembre, p. 62.

Organisation représentative, Qu'est-ce qu'une?' - JeanPierre Després, No 2, octobre, pp. 20-22.

Organisation du travail - No 9, mai, pp. 141-142.

Participation ( $\mathrm{La}$ ) des travailleurs aux bénéfices est-elle un cadeau? - Gérard Dion, No 9, mai, pp. 132-137

Paternité, patronat, paternalisme - Marcel Clément, No 5, Janvier, pp. 65-68.

Paternity, Patronate, Paternalism - Marcel Clément, No. 5, January, p. 80.

Personnel, Le remplacement du - Germain Giroux, No 5, janvier, pp. 69-71.

Personnel Management - Germain Giroux, No. 5, January, pp. 71-73.

Placement, Un bureau de - Jean Gagné, No 3, novembre, pp. 43-44.

Prix, Augmentation de salaire et hausse de - Gérard Dion, No 1, septembre, pp. 5-7.

Profession, Semaine sociale de France et - No 3, novembre, p. 47.

Programme-souvenir, programme d'avenir - No 1, septembre, p. 15 .

Propriété, A propos de - André Roy, No 5, janvier, pp. 68-69.

Propriété et entreprise - Paul-Emile Bolté, p.s.s., No 3 , novembre, pp. 34-40.

Property and Enterprise - Paul-Emile Bolté, p.s.s., No. 3, November, pp. 40-41.

Publications reçues au Département des relations industrielles de Laval, Liste des, No 7, mars, pp. 108-110.

Reforms, Structural - Gérard Dion, No. 3, November, p. 48.

Réformes de structure - Gérard Dion, No 3, novembre, p. 33.

Réformes de structure, L'esprit des: Paternité, patronat, paternalisme - Marcel Clément, No 5, janvier, pp. 65-68. Les problèmes qui se posent - Marcel Clément, No 7, mars, pp. 97-99. La structure de l'entreprise - Marcel Clément, No 6, février, pp. 82-86. Les solutions proposées - Marcel Clément, No 8, avril, pp. 114-116. No 9, mai, pp. 129-132. No 10, juin, pp. 145-148. Propriété et entreprise - PaulEmile Bolté, No 3, novembre, pp. 34-40. Réformes de structure - Gérard Dion, No 3, novembre, p. 33. La participation des travailleurs aux bénéfices est-elle un cadeau? - Gérard Dion, No 9, mai, pp. 132-137.

Reforms, The Spirit of Structural: Paternity, Patronate, Paternalish - Marcel Clément, No. 5, January, p. 80. The Structure of Enterprise - Marcel Clément, No. 6, February, pp. 87-91. The Problems which Present Themselves - Marcel Clément, No. 7, March, pp. 110-11-112. Proposed Solutions - Marcel Clément, No. 8, April, pp. 122-124. No. 9, May, pp. 142-144. No. 10, June, pp. 157-158-160. Property and Enterprise - Paul-Emile Bolté, p.s.s., No. 3, November, pp. 4041. Structural Reforms - Gérard Dion, No. 3, November, p. 48.

Relations du travail, La morale dans les - Gaston Cholette, No 3, octobre, pp. 19-20.

Relations Plan, Our industrital - W.J. Whitehead, No. 4, November, pp. 59, 60, 61, 63.

Salaire, Augmentation de... et hausse de prix - Gérard Dion, No 1, septembre, pp. 5-7.

«Salarié 》 et «Différend », Le sens des termes - MarieLouis Beaulieu, c.r., No 5, janvier, pp. 74-78.

Sécurité syndicale et morale - Gaston Cholette, no 10 , juin, p. 158 .

Solution courageuse, Une - W.J. Whitehead, No 4, décembre, pp. 55-58.

Stabilité ouvrière et distributisme social - Gonzalve Poulin, o.f.m., No 1, septembre, pp. 8-10.

Strike, Political or Economic - The Editors, No. 3, October, p. 32 .

Travail, Humanisation du - J.-T. Delos, No 1, septembre, p. 7 .

Unité syndicale et cartels intersyndicaux - Jean-Pierre Després, No 7, mars, pp. 106-108. 
V-THE METHODS OF REFORM IN STRUCTURE

\section{PROPOSED SOLUTIONS \\ (conclusion) \\ Marcel CLÉMENT}

To finish our rapid review of the principal formulae of structural reform two further experiments of a very particular kind should be considered. Profit-sharing and proportionate salary are so many possible solutions of the problem of how to share profits. The self-governing team is another. Being an extremely flexible method this solution - the self-governing team - goes even further since it tends to reinforce the personality of the worker by approaching successfully the problem if isolation in the factory. As for the Barbu Community, it attempts to solve the problem of the sharing of property under a form very close indeed to co-operation pure and simple.

\section{IV-Self-governing Teams \\ (Dubreuil-Rimailho System)}

The idea of the system of self governing teams is borrowed from a much older formula which had had an exceptional success in printing establishments - the workshop «commandite » of «Companionship » as it was called in the old days. - The workshop «commandite » was the first effort, by a group of workmen, to attain responsible autonomy and thus gain, along witch independance, the possibility of directing their collective efforts.

Its idea is simple. The work is done by a group of workmen who freely share in the task. Payment is collected by a delegated leader of the team and divided among the workers. The block of workers enjoys complete autonomy within the enterprise. For each job to be done, the workshop «commondite », through the intermediary of its accountant, establishes the cost of labour ands passes it on to the employer. This latter adds the cost of raw materials, depreciation etc. If the price is acceptable to the client the employer hands over the job to the chosen leader of the group.

Theoretically remarkable, the workshop «commandite» was disappointing in practice, mostiy because of difficulties in dividing the wages and squabbles over the authority of the delegated leader. In a word, the absence of real authority was soon felt and led to rivalries which resulted finally in the breaking up of the «Companionship».

The Dufreuil-Rimailho system is a tentative attempt to re-establish the succesful elements of the workshop «commandite» while eliminating the radicalism which brought about its failure. In his book «A chacun sa chance », ${ }^{1}$ Monsieur Dubreuil states «The central idea of this work consists of taking, as basis for the re-organizing of an enterprise, all the sub-divisions that cannot be isolated by an analysis carried out after the manner of Godin. These sub-divisions or units when defined, must be accorded an autonomy not only technical but in a sense budgetary, so that the men of each unit would find, through a proportional and equitable sharing of the product of their labour, a nersonal satisfaction comparable to that offered by an independent enterprise. It goes without saying that this autonomy is conceivable only within the limits compatible with the harmony of the whole. In the manner could be established that equilibrium between the personal interest of each individual and the collective interest of the enterprise which is so desirable. All relations within the enterprise, whether between the individual and the group or between the group and the management, would tend then to take a form purely business-like and the idea of subordination - always a source of conflict - would disap-

(1) Bernard Grasset, editor.

(continued on page 158)

\section{IS YOUR SUBSCRIPTION UP FOR RENEWAL NOW ?} WELL, DO NOT DELAY. 